\title{
Fixed point theorems for multivalued generalized contractions with respect to two topologically equivalent metrics
}

\section{IULIA COROIAN}

\section{ABSTRACT.}

In this paper, we will present some fixed point results for multivalued almost contractions with respects to two topologically equivalent Hausdorff type metrics.

Acknowledgement. The author is thankful to the anonymous reviewer(s) for the valuable suggestions and for the open question proposal.

\section{REFERENCES}

[1] Khamsi, M. A. and Kirk, W. A., An Introduction to Metric Spaces and Fixed Point Theory, Pure and Applied Mathematics, Wiley-Interscience, New York, 2001

[2] Kirk, W. A. and Shahzad, N., Remarks on metrics transform and fixed point theorems, 2013, Article ID 9612004682934060

[3] Nadler, S. B., Jr., Multi-valued contraction mappings, Pacific J. Math., 30 (1969), No. 2, 475-487

[4] Rus, I. A., Generalized Contraction and Applications, Cluj Univ. Press, Cluj-Napoca, 2001

[5] Rus, I. A., Petruşel, A. and Petruşel, G., Fixed Point Theory, Cluj University Press, 2008

[6] Petruşel, A., Rus, I. A. and Marcel, M. A., The role of eq metrics in fixed point theory, Topol. Meth. Nonlinear Anal., 41 (2013), 85-112

DEPARTMENT OF MATHEMATICS

BABEŞ-BOLYAI UNIVERSITY ClUJ-NAPOCA

KOGĂLNICEANU 1, 400084 CLUJ-NAPOCA, ROMANIA

E-mail address: coroian.iulia@gmail.com 